\title{
PERILAMPUS, A SECONDARY PARASITE ON SARCOPHA- GIDS AND TACHINIDS PARASITIC ON KATYDIDS AND LONG-HORNED GRASSHOPPERS
}

Ford $^{1}$ reports finding a planidium of Perilampus attached to a long-horned grasshopper, Conocephalus fasciatus. She considers it quite improbable that Conocephalus is the true host of the Perilampus, and that quite likely the planidium is a secondary parasite of some parasite of Conocephalus, because Perilampus has been reared as a secondary parasite from several species of Sarcophagids, though not from Sarcophagids on long-horned grasshoppers. ${ }^{2,3}$

I have reared a Perilampus n. sp. $^{4}$ from one of three puparia collected from the cell of the digger wasp, Ammobia pennsylvanica which uses katydids, Microcentrum rhombifolium (M. laurifolium) for provisioning her cells. The other two puparia yielded a Brachymeria n. sp., and a Sarcophagid fly. The fly was in too poor a condition to allow of identification beyond Sarcophagidæ. The puparia, which were all identical, in structure, were new and as yet unidentified, making it impossible to use them as a means of identifying the fly. The find at least establishes the fact that Perilampus is a secondary parasite on a Sarcophagid parasitic on katydids.

From a collection of over fifty puparia of the Tachinid, Senotainia trilineata (V. d. W.) found in the cells of the same digger wasp, I reared 2 specimen of Perilampus hyalinus (Say). This establishes the fact that Perilampus is a secondary parasite on Senotainia trilineata parasitic on katydids. I have also reared, however, S. trilineata from

1. N. Ford, Canad. Ent., 54:199-204, 1922.

2. H. S. Smith, U S Dept Agr, Bur Ent, Tech Ser 19 (4) :33-69, 1912.

3. E. O. G. Kelly, Jour. Agric. Res., U. S. Dept. Agr., 2:435-445, 1914.

4. Identifications were made by the staff of the Bur. Ent. and Plant Quar., U. S. Dept. Agr. as follows: Orthoptera, A. N. Caudell; Perilamphus, A. B. Gahan; Sarcophagids, J. M. Aldrich and C. T. Greene. 
puparia found in the cells of the digger wasp Ammobia ichneumonea which provisions her nest with long-horned grasshoppers of the species Neoconocephalus ensiger (Conocephalus ensiger) and Conocephalus attenuatum (Xiphidium attenuatum). This confirms the opinion of Ford that the planidium found in Conocephalus fasciatus is a secondary parasite of a Tachinid parasitic on long-horned grasshoppers, in this case Senotainia tritineata.

JoHN A. FrISCH, S. J.

Canisius College, Buffalo, N. Y. 

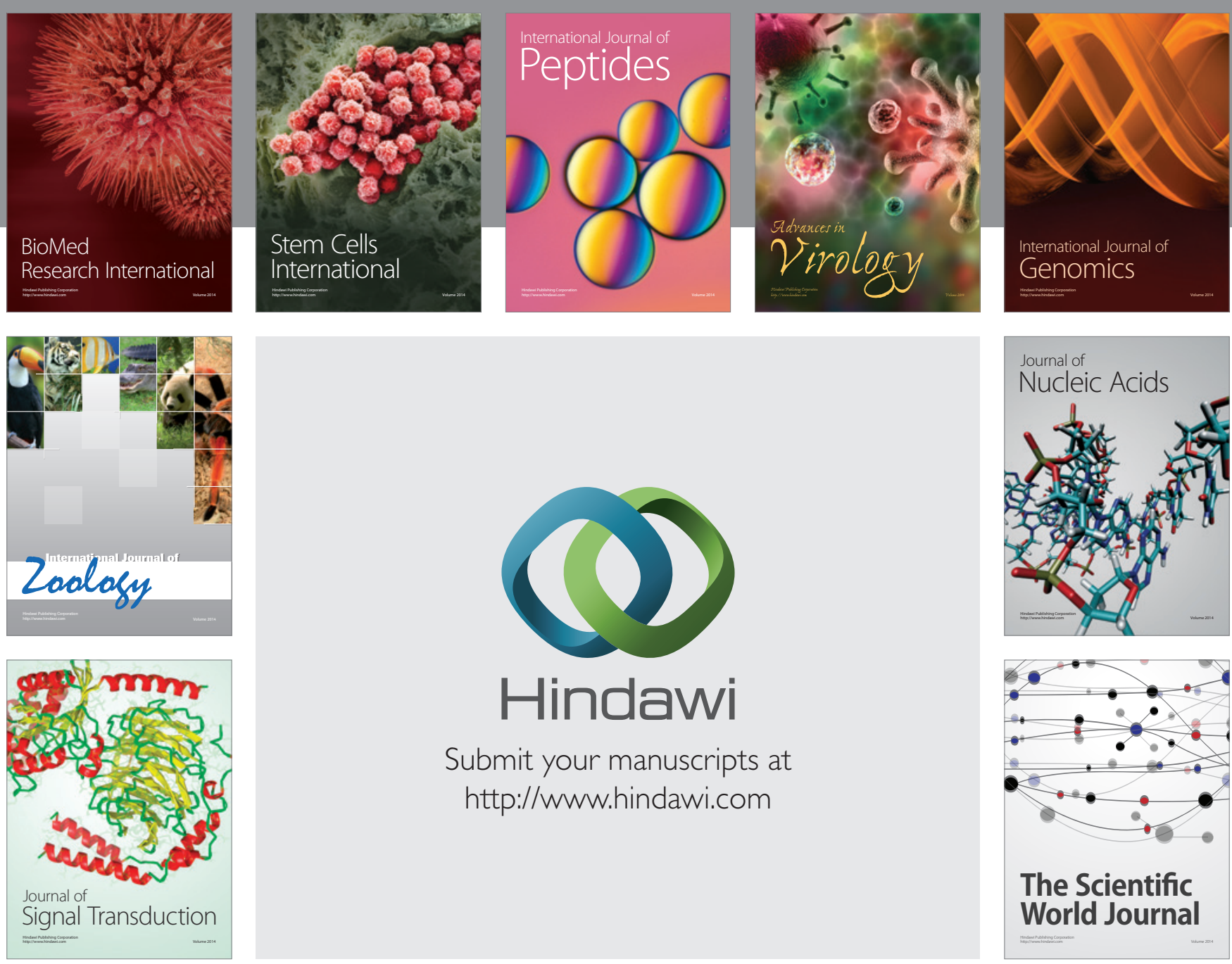

Submit your manuscripts at

http://www.hindawi.com
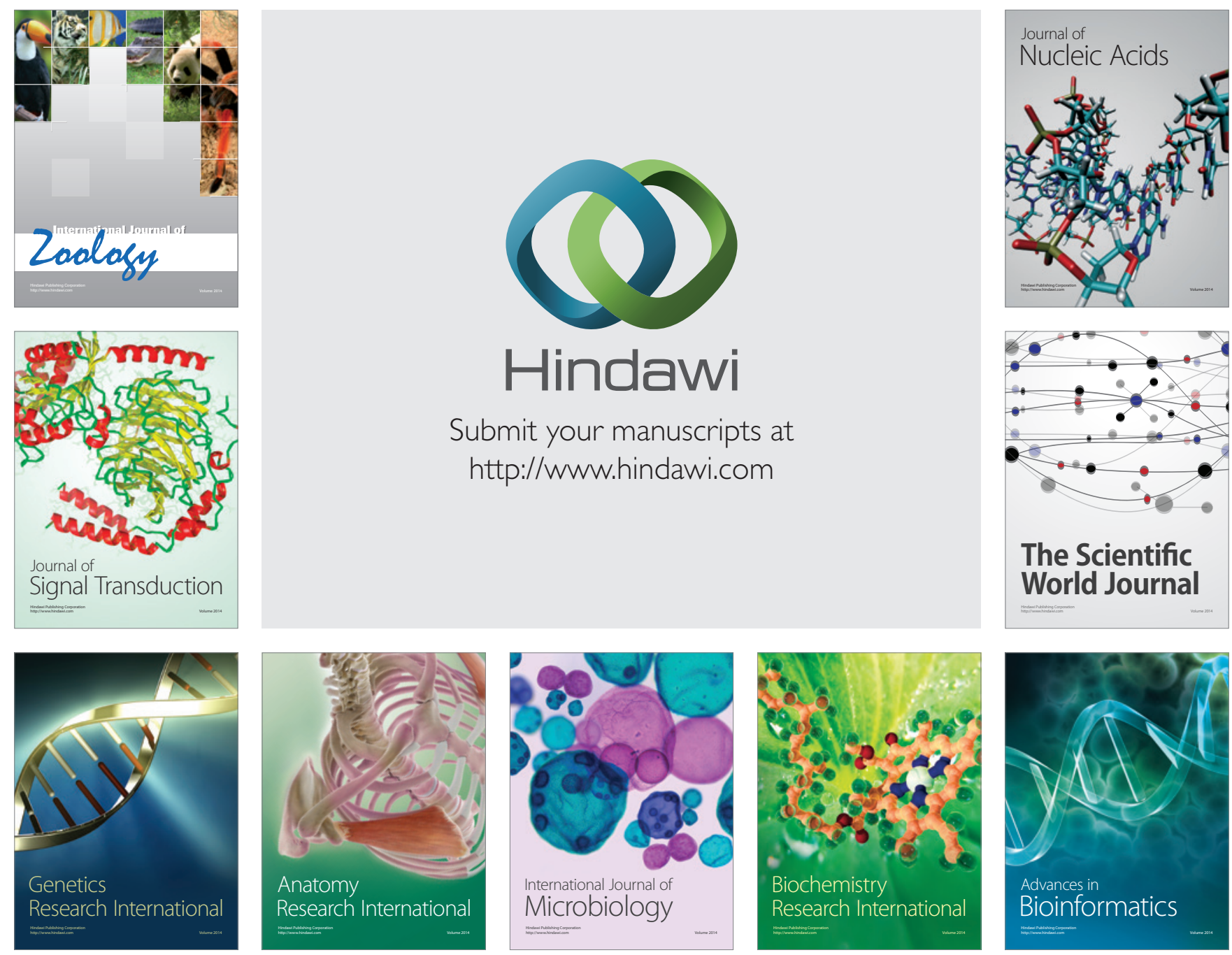

The Scientific World Journal
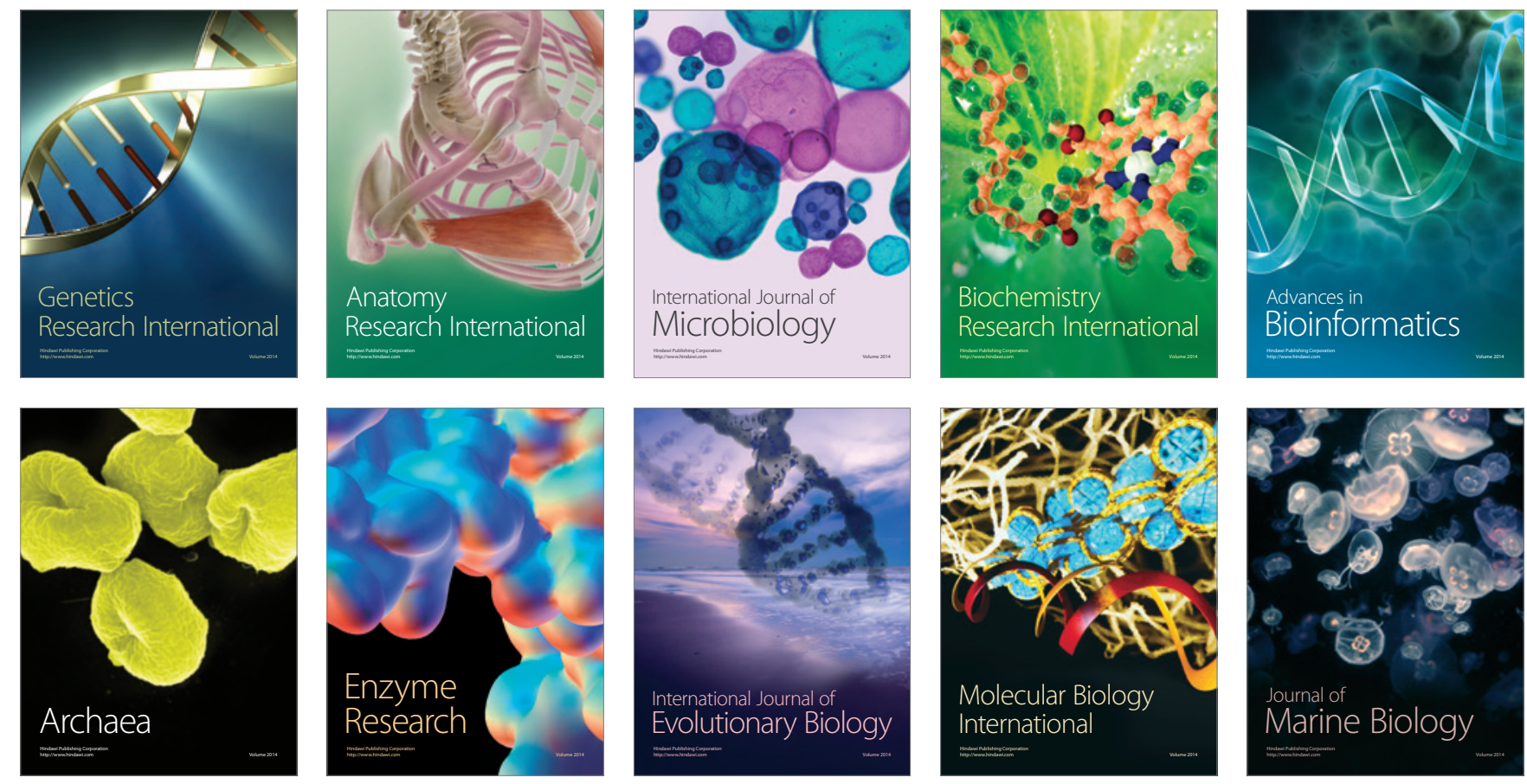